\title{
Correction to: Biology Undergraduate Students' Graphing Practice in Digital Versus Pen and Paper Graphing Environments
}

\author{
Stephanie M. Gardner ${ }^{1}$ - Elizabeth Suazo-Flores ${ }^{2} \cdot$ Susan Maruca ${ }^{3}$. Joel K. Abraham ${ }^{4} \cdot$ Anupriya Karippadath $^{1}$. \\ Eli Meir ${ }^{3}$
}

Published online: 12 May 2021

(c) Springer Nature B.V. 2021

\section{Correction to: Journal of Science Education and Technology https://doi.org/10.1007/s10956-020-09886-w}

The original version of this article unfortunately contained a mistake. The name of "Susan Maruca" is now corrected in the author group.

The original article has been corrected.

Publisher's Note Springer Nature remains neutral with regard to jurisdictional claims in published maps and institutional affiliations.

The original article can be found online at https://doi.org/10.1007/ s10956-020-09886-w.

Stephanie M. Gardner

sgardne@purdue.edu

1 Department of Biological Sciences, Purdue University, 915

West State Street, West Lafayette, IN 47907, USA

2 Center for Advancing the Teaching and Learning of STEM

Department of Curriculum and Instruction, BRNG, 4166

Purdue University, 100 N. University Street, West Lafayette,

IN 47907-2098, USA

3 SimBiotic Software, Inc, P.O. Box 7158, Missoula, MT 59807, USA

4 Department of Biological Science, California State University-Fullerton, 800 North State College Blvd, Fullerton, CA 92831, USA 